\title{
The Effect of Corn Silage Particle Size on Eating Behavior, Chewing Activities, and Rumen Fermentation in Lactating Dairy Cows
}

\author{
P. J. Kononoff, ${ }^{1}$ A. J. Heinrichs, and H. A. Lehman \\ Department of Dairy and Animal Science \\ The Pennsylvania State University, University Park 16802
}

\begin{abstract}
The objective of this experiment was to evaluate effects of reducing corn silage particle size on eating behavior, chewing activity, and rumen fermentation in lactating dairy cows. Four cannulated, multiparous cows averaging $110 \pm 4 \mathrm{~d}$ in milk and weighing $675 \pm$ $70 \mathrm{~kg}$ were randomly assigned to a $4 \times 4$ Latin square. During each of four 14-d periods, animals were offered one of four diets that were chemically similar but varied in corn silage particle size: short (SH), mostly short (MSH), mostly long (MLG), and long (LG), with a geometric mean particle length of 7.4, 7.8, 8.3, and 8.8 $\mathrm{mm}$, respectively. Reducing particle size increased dry matter intake (DMI) linearly (28.0, 26.8, 26.8, and 25.7 $\mathrm{kg} / \mathrm{d}$ for $\mathrm{SH}, \mathrm{MSH}, \mathrm{MLG}$, and LG respectively). At 8, 16 , and $24 \mathrm{~h}$ postfeeding, the neutral detergent fiber (NDF) concentration of feed remaining in the bunk decreased linearly with reduced particle size. Time spent eating or ruminating was not different across treatments; however, total chewing activity (TC; sum of time spent eating and ruminating) exhibited a quadratic response with highest chewing activities observed for diets with shortest and longest particle size. Eating or ruminating time per kilogram of DMI was not affected by corn silage particle size, but TC per kilogram of DMI decreased linearly with decreasing particle size. In comparison, when expressed as minutes per unit of NDF intake (NDFI), ruminating, and TC were linearly reduced as particle size decreased. Rumen $\mathrm{pH}$ was not affected by corn silage particle size even though total concentration of volatile fatty acids increased linearly from $89.1 \mathrm{~m} M / \mathrm{L}$ to $93.6 \mathrm{mM} / \mathrm{L}$ as diet particle size decreased. A quadratic effect was observed in molar proportion of acetate and propionate with the highest concentration observed in animals consuming diets of intermediate particle size. Results of this experiment suggest that reducing corn silage
\end{abstract}

Received January, 162003.

Accepted March 30, 2003.

Corresponding author: A. J. Heinrichs; e-mail: ajh@psu.edu.

${ }^{1}$ Current address: Dept. of Animal and Nutritional Sciences, University of New Hampshire, Durham. particle size may increase DMI, positively affect rumen fermentation, and reduce sorting behavior. Because both chewing activity and sorting tendencies increased when proportion of TMR particles $>19.0 \mathrm{~mm}$ increased, results suggest that particle size measurement as estimated by the PSPS is useful in understanding some factors that affect feeding behavior.

(Key words: rumen, eating behavior, $\mathrm{pH}$, rumination)

Abbreviation key: $\mathbf{L G}=$ long treatment containing long harvested corn silage, MLG = intermediate long treatment composed of 2 parts LG, 1 part SH (DM basis), MSH = intermediate short treatment composed of 1 part LG, 2 parts SH (DM basis), NDFI = neutral detergent fiber intake, peNDF = physically effective neutral detergent fiber, PSPS $=$ Penn State Particle Separator, $\mathbf{S}_{\mathbf{g m}}=$ geometric standard deviation, $\mathbf{S H}=$ short treatment containing rechopped corn silage, TC = total chewing activity, $\mathbf{T C L}=$ theoretical cut length, $\mathbf{X}_{\mathbf{g m}}=$ geometric mean length.

\section{INTRODUCTION}

Due to its energy value, fiber content, and high yielding properties, corn is viewed as an ideal crop for ensiling. Hybrid, maturity, and moisture content at feeding are known indicators of the nutritional value of corn silage (Johnson et al., 2002). In addition to these factors, fine chopping during harvest improves packing density and fermentation and presumably aids in maintaining nutritive value (McDonald, 1981); however, the effect of corn silage particle size on the lactating cow is less clear.

It is commonly believed that feeding forage of short particle size will decrease salivary buffer secretion, ultimately lowering rumen $\mathrm{pH}$ and milk fat percentage (Mertens, 1997). More specifically, the cascade of these events is believed to be precipitated by diets low in physically effective fiber, which is defined as that portion of the diet that stimulates chewing activity and salivary buffer production. Because fiber content of the diet is a primary factor affecting chewing activity, both are believed to be indicators of the diet's effect on rumen health and function (Yang et al., 2001). Phys- 
ically effective NDF (peNDF) is an estimate of physically effective fiber and is calculated by multiplying the proportion of feed greater than $1.18 \mathrm{~mm}$ in length by total ration NDF (Mertens, 1997). Although a number of studies have recently evaluated the relationships between peNDF, chewing activity, and rumen $\mathrm{pH}$, information regarding corn silage-based diets remains limiting (Yang et al., 2001; Krause et al., 2002).

Mastication reduces particle size of ingested feed and is necessary for the consumption of feed, thus it follows that physical manipulation of feed may affect chewing activities. A number of studies have attempted to determine the effects of reducing forage particle size through grinding (Rodrigue and Allen, 1960), fine chopping (Bal et al., 2000) or pelleting (Woodford and Murphy, 1988) on chewing activities and feeding behavior. Although it is generally understood that both eating and ruminating time increase per unit of DM or NDF consumed when feeds of longer particle size are fed, data are lacking on the effects on consumption of total DM, NDF, or the proportion of particles consumed over time. Supplying the rumen with a uniform supply of nutrients throughout the day should lead to a more constant environment for bacterial and protozoa growth. Alternatively, if ingestion is rapid or selective, large diurnal variation in acid production may result in subacute ruminal acidosis (Van Soest, 1994).

The Penn State Particle Separator (PSPS) is a quick and cost-effective method to estimate forage and TMR particle size and was constructed as an on-farm alternative to the standard S424 of the American Society of Agricultural Engineers (2001) for particle size determination. The compact, manually operated sieving device is constructed of three sieves with pores measuring 19.0, 8.0, and $1.18 \mathrm{~mm}$ and a solid bottom pan (Kononoff et al., 2003). Though the apparatus has been widely accepted, few studies have attempted to describe effects of feeding forage of different particle size as measured by the PSPS.

The objective of the present experiment was to determine the effect of feeding corn silage of different particle size on eating behavior, chewing activities, and rumen fermentation in lactating dairy cows. It was hypothesized that rations of shortest particle size would be consumed in greatest amounts but result in lowest chewing activity and rumen $\mathrm{pH}$. Alternatively, rations of longest particle size would be consumed in least amounts and result in greatest amounts of bunk sorting activity.

\section{MATERIALS AND METHODS}

\section{Diets, Animals, and Experimental Design}

Pioneer corn hybrid 34K77 (Pioneer Hi-Bred International, Des Moines, IA) was harvested at $30.6 \pm 1.9 \%$
Table 1. Corn silage chemical composition and fermentation measures.

\begin{tabular}{lcl}
\hline & Mean & SD \\
\hline DM, \% & 30.6 & 1.9 \\
CP, \%DM & 9.3 & 0.7 \\
Soluble protein, \%DM & 5.1 & 0.5 \\
Ether extract, \%DM & 2.8 & 0.2 \\
NDF, \%DM & 39.6 & 2.1 \\
NDICP, \%DM & 1.4 & 0.02 \\
ADF, \%DM & 22.4 & 1.3 \\
Lignin, \%DM & 3.1 & 0.06 \\
TNC, \%DM & 2.9 & 2.8 \\
NFC, \%DM & 34.9 & 2.7 \\
Ca, \%DM & 46.2 & 0.05 \\
P,\%DM & 0.3 & 0.04 \\
Mg, \%DM & 0.3 & 0.02 \\
K, \%DM & 0.2 & 0.1 \\
pH & 1.2 & 0.1 \\
Ammonia, \%DM & 3.7 & 0.06 \\
Lactic acid, \%DM & 0.5 & 0.8 \\
Acetic acid, \%DM & 5.1 & 0.4 \\
Butyric acid, \%DM & 0.5 & $\ldots$ \\
Propionic acid, \%DM & $<0.01$ & $\ldots$ \\
Isobutyric acid, \%DM & $<0.01$ & $\ldots$ \\
\hline
\end{tabular}

${ }^{1} \mathrm{NDICP}=$ neutral detergent insoluble CP.

${ }^{2} \mathrm{TNC}=$ total nonstructural carbohydrates (Smith, 1981).

${ }^{3} \mathrm{NFC}=$ nonfiber carbohydrate; calculated by difference: $100-(\%$ $\mathrm{NDF}+\% \mathrm{CP}+\% \mathrm{Fat}+\% \mathrm{ASH})$.

DM. Silage was harvested using a self-propelled forage harvester (John Deere, model 6750) set at $22.3 \mathrm{~mm}$ theoretical cut length (TCL). Although this harvester was equipped with a kernel processor it was not used. The chopped material was then placed in a concrete bunker, covered with black plastic, ensiled for approximately $100 \mathrm{~d}$, and designated "long" forage. Every second day during the experiment, silage was rechopped using a pull type forage harvester (New Holland, model 900) set at $4.8-\mathrm{mm}$ TCL, stored at $4^{\circ} \mathrm{C}$, and designated "short" forage. Nutrient composition and particle size measurements of corn silage are presented in Tables 1 and 2 .

Four ruminal cannulated, lactating, multiparous Holstein cows averaging $110 \pm 4$ DIM and weighing

Table 2. Particle size distribution (\%DM retained), geometric mean $\left(\mathrm{X}_{\mathrm{gm}}\right)$, and standard deviation $\left(\mathrm{S}_{\mathrm{gm}}\right)$ for ensiled and rechopped corn silage as measured by the Penn State Particle Separator.

\begin{tabular}{lccl}
\hline & Ensiled & Rechopped & SEM \\
\hline \%DM retained & & & \\
$>19.0 \mathrm{~mm}$ & 25.9 & 6.8 & 1.0 \\
19.0 to $8.0 \mathrm{~mm}$ & 59.3 & 65.2 & 0.9 \\
8.0 to $1.18 \mathrm{~mm}$ & 14.2 & 27.1 & 0.5 \\
$<1.18 \mathrm{~mm}$ & 0.6 & 0.9 & 0.1 \\
$\mathrm{X}_{\mathrm{gm}}(\mathrm{mm})^{1}$ & 12.9 & 9.2 & 0.2 \\
$\mathrm{~S}_{\mathrm{gm}}(\mathrm{mm})^{2}$ & 1.96 & 1.93 & 0.02 \\
\hline${ }^{1} \mathrm{X}_{\mathrm{gm}}=$ calculated geometric mean length (ASAE, 2001). \\
${ }^{2} \mathrm{~S}_{\mathrm{gm}}=$ calculated standard deviation (ASAE, 2001).
\end{tabular}


$675 \pm 70 \mathrm{~kg}$ were randomly assigned a $4 \times 4$ Latin square. During each of the 14-d periods, animals were offered one of four chemically similar TMR that differed in forage particle size. Diets were composed of either long (LG) or short (SH) forage or mixtures of these diets. Diet mostly long (MLG) was composed of two parts LG TMR and one part SH TMR (DM basis). Diet mostly short (MSH) was composed of one part LG TMR and two parts SH TMR (DM basis).

Animals were housed in individual stalls and milked at 0700 and $1900 \mathrm{~h}$. Cows were fed at $0800 \mathrm{~h}$ for ad libitum consumption to allow for approximately $5.0 \%$ refusal. Cows were cared for and maintained according to guidelines stipulated by the Pennsylvania State University Animal Care and Use Committee.

\section{Experimental Measures and Sample Analysis}

Samples of feed were collected daily, and composite samples were made for each week of the experiment. Orts from individual cows were collected daily for calculation of DMI and NDFI (NDF intake). Collected samples were immediately frozen $\left(-20^{\circ} \mathrm{C}\right)$ and stored for further analysis. Samples were then dried at $55^{\circ} \mathrm{C}$ in a forced-air oven to determine moisture content and then ground (1-mm screen; Wiley Mill, Arthur A. Thomas Co., Philadelphia, PA). All TMR and forage samples were analyzed in duplicate for moisture; Kjeldahl nitrogen (CP) using a Kjetec 1030 auto analyzer; ether extract; calcium and phosphorus; magnesium; potassium; and ash (AOAC, 1990). Neutral detergent fiber, $\mathrm{ADF}$, and acid detergent lignin were analyzed according to the procedure of Van Soest et al. (1991). Neutral detergent insoluble CP was analyzed on NDF residue. Heat stable alpha-amylase (number A3306; Sigma Chemical Co., St. Louis, MO) was included in the NDF procedure (100 $\mu \mathrm{l} / 0.5 \mathrm{~g}$ of sample). Nonfiber carbohydrate was calculated by difference: $100-(\%$ $\mathrm{NDF}+\% \mathrm{CP}+\%$ Fat $+\%$ ASH). Total nonstructural carbohydrate was determined according to the procedure of Smith (1981), but modified to use ferricyanide as a colorimetric indicator. The PSPS was used to measure particle size for both forage and TMR (Kononoff et al., 2003a).

On d 7 and 8 of each period, feed bunk contents of each animal were weighed and sampled at $0,8,16$, and $24 \mathrm{~h}$ after a.m. feeding to determine particle size, DMI, and NDFI. All samples were sieved in duplicate and placed in a forced air oven at $55^{\circ} \mathrm{C}$ to determine $\mathrm{DM}$ of each sieved fraction.

Eating and ruminating activities were measured during d 12 and 13 of each period using Graze Jaw Movement Analysis Software of the IGER Behavior Recorder (Ultra Sound Advice, London, UK) as de- scribed by Rutter et al. (1997) and validated with TMR diets by Kononoff et al. (2002). Data were expressed as daily eating, ruminating, or total chewing activity (TC; sum of eating and ruminating time over $24 \mathrm{~h}$ ). Activities per unit of DMI and NDFI were also calculated by dividing total minutes by the mean of each parameter measured.

On d 13 of each period, ruminal contents were collected from the dorsal, ventral, and caudal area of the rumen at $0.0,1.5,3.5,5.5,8.5,11.5,14.5,18,21.5$, and $24.5 \mathrm{~h}$ after a.m. feeding $(0.0 \mathrm{~h})$. Collected digesta was mixed and filtered through four layers of cheesecloth. Rumen liquid $\mathrm{pH}$ was immediately determined using a handheld pH electrode (model M90, Corning Inc., Corning, NY). Approximately $15 \mathrm{ml}$ of filtered liquid was then placed into bottles containing $3 \mathrm{ml}$ of $25 \%$ metaphosphoric acid and $3 \mathrm{ml}$ of $0.6 \% 2$-ethly butyric acid (internal standard) and stored at $-20^{\circ} \mathrm{C}$. Samples were later centrifuged three times at $4000 \times \mathrm{g}$ for 30 min at $4^{\circ} \mathrm{C}$ to obtain a clear supernatant, which was analyzed for ammonia using a phenol-hypochlorite assay (Broderick and Kang, 1980) and VFA concentration using gas chromatography (Yang and Varga, 1989).

Milk production was recorded daily on d 13 to 15 of each period; samples were collected and preserved using 2-bromo-2-nitropropane-1,3 diol. Milk samples were analyzed for milk fat and true protein by the Pennsylvania DHIA milk testing laboratory using infrared spectrophotometry (AOAC, 1990; Foss 605B Milk-Scan; Foss Electric, Hillerød, Denmark).

Performance, intake, and chewing activity data were analyzed as a $4 \times 4$ Latin Square with model effects for cow, period, and treatment. The first order autoregressive covariance structure $(\mathrm{AR}(1))$ and the MIXED procedure of SAS, Version 8.1 (1999) were used to analyze all data. Mean separation for TMR particle size, NDF content by particle size, and peNDF was determined using the PDIFF procedure. Repeated measurements of rumen ammonia, $\mathrm{pH}$, and VFA concentration and ration and refusal particle size were analyzed by including a REPEATED model statement, as well as terms for time and interaction of treatment by time. All means presented are LSMEANS and for ammonia, $\mathrm{pH}$, and VFA are an average over all time points. Linear, quadratic, and cubic orthogonal contrasts were tested using the CONTRAST statement of SAS (1999). Significance for all effects was declared at $P \leq 0.10$.

\section{RESULTS}

\section{Corn Silage and TMR Particle Size and Effective Fiber}

Chemical and physical description of corn silage used in the experiment is presented in Tables 1 and 
Table 3. Ingredient and nutrient composition of TMR.

\begin{tabular}{|c|c|c|c|}
\hline & SHORT & LONG & SEM \\
\hline \multicolumn{4}{|l|}{ Diet ingredients, \% } \\
\hline Corn silage & 57.4 & 57.4 & \\
\hline Ground corn & 11.2 & 11.2 & $\ldots$ \\
\hline Roasted soybeans & 6.1 & 6.1 & $\ldots$ \\
\hline Distillers grain & 6.9 & 6.9 & $\ldots$ \\
\hline Wheat middlings & 6.9 & 6.9 & $\ldots$ \\
\hline Soybean meal & 6.7 & 6.7 & $\ldots$ \\
\hline Blood, feather, fish meal & 1.8 & 1.8 & $\ldots$ \\
\hline Salt & 0.5 & 0.5 & $\ldots$ \\
\hline Magnesium oxide & 0.4 & 0.4 & $\ldots$ \\
\hline Limestone & 1.5 & 1.5 & $\ldots$ \\
\hline Calcium sulfate & 0.3 & 0.3 & $\ldots$ \\
\hline Trace mineral $\operatorname{mix}^{1}$ & 0.02 & 0.02 & $\ldots$ \\
\hline Urea & 0.4 & 0.4 & $\ldots$ \\
\hline Vitamin $\mathrm{ADE}^{2}$ & 0.02 & 0.02 & $\ldots$ \\
\hline \multicolumn{4}{|l|}{ Chemical } \\
\hline Moisture, \% & 56.8 & 55.7 & 1.3 \\
\hline Ash, \%DM & 7.6 & 7.3 & 0.2 \\
\hline $\mathrm{CP}, \% \mathrm{DM}$ & 16.3 & 16.4 & 0.5 \\
\hline $\mathrm{NDF}, \% \mathrm{DM}$ & 32.9 & 33.2 & 0.4 \\
\hline Ether extract, \%DM & 4.7 & 4.6 & 0.1 \\
\hline $\mathrm{ADF}, \% \mathrm{DM}$ & 18.1 & 18.9 & 0.3 \\
\hline $\mathrm{NFC}, \% \mathrm{DM}^{3}$ & 38.8 & 38.0 & 0.5 \\
\hline
\end{tabular}

${ }^{1}$ Contained $0.57 \% \mathrm{Ca}, 1362 \mathrm{mg} / \mathrm{kg}$ of $\mathrm{Co}, 40,816 \mathrm{mg} / \mathrm{kg}$ of $\mathrm{Cu}, 2,725$ $\mathrm{mg} / \mathrm{kg}$ of I, $10,204 \mathrm{mg} / \mathrm{kg}$ of $\mathrm{Fe}, 1,222,449 \mathrm{mg} / \mathrm{kg}$ of $\mathrm{Mn}, 156 \% \mathrm{~S}$, $122,450 \mathrm{mg} / \mathrm{kg}$ of $\mathrm{Zn}$.

${ }^{2}$ Contained $13,043 \mathrm{KIU}$ vitamin $\mathrm{A}, 3261 \mathrm{KIU}$ vitamin $\mathrm{D}, 81,521$ IU vitamin $\mathrm{E}$.

${ }^{3} \mathrm{NFC}=$ nonfiber carbohydrate calculated by difference $100-(\%$ $\mathrm{NDF}+\% \mathrm{CP}+\% \mathrm{Fat}+\% \mathrm{ASH})$.

2. Total mixed ration composition and particle size analysis are presented in Tables 3 and 4 . Ration particle size reflected the amount of rechopped forage in- cluded in the treatments. Rechopping forage reduced the proportion of material on the 19.0-mm screen, but increased proportion on the 8.0 - and $1.18-\mathrm{mm}$ screens of the PSPS. Although the proportion of particles $<1.18$ $\mathrm{mm}$ increased with decreasing particle size, differences were not significant. Geometric mean length decreased linearly as the amount of rechopped forage in the TMR decreased. The peNDF value, as measured by the proportion of NDF $>1.18 \mathrm{~mm}$, decreased numerically with decreasing particle size, but these differences were small and not significant.

\section{Intake and Chewing Activities}

Intake data of DM and NDF are presented in Table 5. As particle size decreased there was a linear increase in DMI and NDFI. The largest difference in total DMI and NDFI was observed between SH and LG treatments ( $2.3 \mathrm{~kg}$ of DM and $0.8 \mathrm{~kg}$ of NDF). Feed refusal samples were analyzed for NDF to evaluate sorting in the feed bunk, and concentration of NDF in ort samples decreased with reduced particle size. The smallest numerical differences in NDF concentration between orts and TMR were observed in animals consuming the $\mathrm{SH}$ treatments and largest differences in animals consuming LG.

The effects of corn silage physical form on eating and ruminating activities are presented in Table 6. Differences in time spent eating or ruminating were not detected between treatments; however, TC exhibited a quadratic effect with highest chewing activities

Table 4. Effects of reducing corn silage particle size on TMR particle size distribution, geometric mean, and standard deviation, NDF content, and physically effective NDF (peNDF).

\begin{tabular}{|c|c|c|c|c|c|c|}
\hline & \multicolumn{4}{|c|}{ Treatment $^{1,2}$} & \multirow[b]{2}{*}{$P$ value } & \multirow[b]{2}{*}{ SEM } \\
\hline & $\mathrm{SH}$ & $\mathrm{MSH}$ & MLG & LG & & \\
\hline \multicolumn{7}{|l|}{$\%$ DM retained } \\
\hline$>19.0 \mathrm{~mm}$ & $2.9^{\mathrm{d}}$ & 6.7 & $11.1^{\mathrm{b}}$ & $15.5^{\mathrm{a}}$ & $<0.01$ & 0.8 \\
\hline $19.0-8.0 \mathrm{~mm}$ & $57.5^{\mathrm{a}}$ & $55.7^{\mathrm{b}}$ & $53.2^{\mathrm{c}}$ & $50.3^{\mathrm{d}}$ & $<0.01$ & 0.5 \\
\hline $8.0-1.18 \mathrm{~mm}$ & $35.3^{\mathrm{a}}$ & $33.8^{\mathrm{ab}}$ & $31.9^{\mathrm{ab}}$ & $30.3^{\mathrm{c}}$ & $<0.01$ & 0.8 \\
\hline$<1.18 \mathrm{~mm}$ & 4.2 & 4.0 & 3.9 & 3.9 & 0.88 & 0.2 \\
\hline $\mathrm{X}_{\mathrm{gm}}(\mathrm{mm})^{3}$ & 7.4 & $7.8^{\mathrm{c}}$ & $8.3^{\mathrm{ab}}$ & $8.8^{\mathrm{a}}$ & $<0.01$ & 0.2 \\
\hline $\mathrm{S}_{\mathrm{gm}}(\mathrm{mm})^{4}$ & $2.1^{\mathrm{c}}$ & $2.2^{\mathrm{b}}$ & 2.3 & 2.4 & $<0.01$ & 0.02 \\
\hline \multicolumn{7}{|l|}{$\%$ NDF (DM) } \\
\hline$>19.0 \mathrm{~mm}$ & $55.6^{\mathrm{c}}$ & $57.2^{\mathrm{bc}}$ & $58.8^{\mathrm{ab}}$ & $60.4^{\mathrm{a}}$ & $<0.01$ & 0.6 \\
\hline $19.0-8.0 \mathrm{~mm}$ & $34.2^{\mathrm{a}}$ & $33.7^{\mathrm{ab}}$ & $33.1^{\mathrm{ab}}$ & $32.5^{\mathrm{b}}$ & $<0.01$ & 0.2 \\
\hline $8.0-1.18 \mathrm{~mm}$ & $25.9^{\mathrm{a}}$ & $25.1^{\mathrm{b}}$ & $24.4^{\mathrm{c}}$ & $23.6^{\mathrm{d}}$ & $<0.01$ & 0.2 \\
\hline$<1.18 \mathrm{~mm}$ & 17.0 & 17.4 & 17.7 & 18.1 & 0.13 & 0.3 \\
\hline$\%$ peNDF $(\mathrm{DM})^{5}$ & 31.7 & 31.9 & 32.0 & 32.1 & 0.91 & 0.4 \\
\hline
\end{tabular}

${ }^{1} \mathrm{SH}=\mathrm{TMR}$ containing short corn silage, $\mathrm{LG}=\mathrm{TMR}$ containing long corn silage, $\mathrm{MSH}=\mathrm{TMR}$ composed of 1 part LG, 2 parts SH, MLG = TMR composed of 2 parts LG, 1 part SH.

${ }^{2}$ Means in the same row with different superscripts differ $(P<0.05)$.

${ }^{3} \mathrm{X}_{\mathrm{gm}}=$ calculated geometric mean length (ASAE, 2001).

${ }^{4} \mathrm{~S}_{\mathrm{gm}}=$ calculated standard deviation (ASAE, 2001).

${ }^{5}$ peNDF $=$ physically effective NDF; ration NDF multiplied by DM $>1.18 \mathrm{~mm}$. 
Table 5. Effects of reducing corn silage particle size on, intake, and NDF content of refusals of lactating dairy cattle.

\begin{tabular}{|c|c|c|c|c|c|c|c|c|}
\hline & \multicolumn{4}{|c|}{ Treatment $^{1}$} & \multirow[b]{2}{*}{ SEM } & \multicolumn{3}{|c|}{ Contrast } \\
\hline & $\mathrm{SH}$ & $\mathrm{MSH}$ & MLG & LG & & Linear & Quadratic & Cubic \\
\hline $\mathrm{BW}, \mathrm{kg}$ & 687.7 & 692.8 & 694.7 & 694.5 & 33.7 & 0.20 & 0.44 & 0.95 \\
\hline $\mathrm{DMI},{ }^{2} \mathrm{~kg} / \mathrm{d}$ & 28.0 & 26.8 & 26.8 & 25.7 & 0.9 & 0.06 & 0.96 & 0.42 \\
\hline $\mathrm{DMI}^{2} \% \mathrm{BW}$ & 4.1 & 3.9 & 3.9 & 3.7 & 0.2 & 0.06 & 0.91 & 0.39 \\
\hline NDF intake ${ }^{2} \mathrm{~kg} / \mathrm{d}$ & 8.9 & 8.5 & 8.4 & 8.1 & 0.3 & $<0.01$ & 0.63 & 0.51 \\
\hline NDF refusal, ${ }^{2} \%$ & 33.8 & 37.3 & 39.1 & 42.1 & 1.7 & $<0.01$ & 0.83 & 0.68 \\
\hline
\end{tabular}

${ }^{1} \mathrm{SH}=$ TMR containing short corn silage, $\mathrm{LG}=$ TMR containing long corn silage, $\mathrm{MSH}=\mathrm{TMR}$ composed of 1 part LG, 2 parts SH, MLG = TMR composed of 2 parts LG, 1 part SH.

${ }^{2}$ As measured on d 12, 13, and 14 of each period.

observed for animals consuming diets with shortest and longest particle size. Eating and ruminating times per kilogram of DMI were not affected by corn silage particle size, but TC per kilogram of DMI decreased linearly as particle size was reduced. In contrast, when expressed as minutes per unit of NDFI, ruminating, and TC were reduced linearly with reduced particle size.

\section{Eating Behavior and Particle Size}

Intake of DM at 8,16 , and $24 \mathrm{~h}$ postfeeding are presented in Table 7. A quadratic effect of particle size was observed $8 \mathrm{~h}$ postfeeding, but DMI increased linearly as particle size was reduced after 16 and 24 $\mathrm{h}$. The concentration of NDF in feed contained in the bunk at $0,8,16$, and $24 \mathrm{~h}$ postfeeding is presented in Figure 1. The concentration of NDF in feed remaining in the bunk at 8,16 , and $24 \mathrm{~h}$ decreased linearly with reduced particle size. Although no differences in NDFI were observed $8 \mathrm{~h}$ postfeeding, NDFI increased lin- early with reduced particle size after 16 and $24 \mathrm{~h}$ (Table 7).

Particle size of TMR and feed remaining in the bunk 8,16 , and $24 \mathrm{~h}$ after feeding are presented in Table 8. Reducing corn silage particle size linearly decreased the proportion of particles $>19.0 \mathrm{~mm}$ and increased the proportion of particles 8.0 to $19.0 \mathrm{~mm}$ and 1.18 to $8.0 \mathrm{~mm}$. Differences between treatments increased over time. Total mixed rations containing $\mathrm{SH}$ forage contained $12.6 \%$ less mass retained on the $19.0-\mathrm{mm}$ sieve when compared to TMR containing LG forage, but this difference increased to over $50 \%$ after $24 \mathrm{~h}$. In comparison, TMR containing $\mathrm{SH}$ forage contained $7.2 \%$ more mass retained on the $8.0 \mathrm{~mm}$ sieve, but this difference increased almost 30\% after $24 \mathrm{~h}$. Lastly, TMR containing SH forage contained $5.0 \%$ more mass retained on the 1.18-mm sieve but contained over $20 \%$ more after $24 \mathrm{~h}$. Although the proportion of material $<1.18 \mathrm{~mm}$ in original TMR was not different across treatments, by $24 \mathrm{~h}$ a linear effect of reducing corn silage particle size was observed for this fraction. Com-

Table 6. Effects of reducing corn silage particle size on chewing activities of lactating dairy cattle.

\begin{tabular}{|c|c|c|c|c|c|c|c|c|}
\hline & \multicolumn{4}{|c|}{ Treatment $^{1}$} & \multirow[b]{2}{*}{ SEM } & \multicolumn{3}{|c|}{ Contrast } \\
\hline & $\mathrm{SH}$ & MSH & MLG & LG & & Linear & Quadratic & Cubic \\
\hline \multicolumn{9}{|l|}{$\mathrm{Min} / \mathrm{d}$} \\
\hline Eating & 201.5 & 214.2 & 185.1 & 212.5 & 25.2 & 0.96 & 0.75 & 0.40 \\
\hline Ruminating & 446.5 & 413.7 & 420.2 & 454.4 & 15.9 & 0.62 & 0.11 & 0.87 \\
\hline $\mathrm{TC}^{2}$ & 651.1 & 627.6 & 604.9 & 663.8 & 27.0 & 0.88 & 0.09 & 0.49 \\
\hline \multicolumn{9}{|l|}{$\mathrm{Min} / \mathrm{kg} \mathrm{DMI}$} \\
\hline Eating & 7.4 & 8.1 & 7.1 & 8.5 & 0.8 & 0.51 & 0.68 & 0.29 \\
\hline Ruminating & 16.3 & 15.3 & 16.4 & 17.9 & 0.9 & 0.14 & 0.18 & 0.67 \\
\hline $\mathrm{TC}$ & 23.5 & 23.6 & 23.4 & 26.5 & 0.9 & 0.04 & 0.08 & 0.37 \\
\hline \multicolumn{9}{|l|}{$\mathrm{Min} / \mathrm{kg} \mathrm{NDFI}{ }^{3}$} \\
\hline Eating & 23.8 & 25.0 & 23.4 & 26.6 & 2.8 & 0.54 & 0.73 & 0.56 \\
\hline Ruminating & 50.9 & 47.7 & 52.0 & 56.0 & 2.4 & 0.08 & 0.17 & 0.46 \\
\hline $\mathrm{TC}$ & 74.4 & 74.4 & 74.6 & 82.1 & 3.3 & 0.09 & 0.21 & 0.63 \\
\hline
\end{tabular}

${ }^{1} \mathrm{SH}=\mathrm{TMR}$ containing short corn silage, $\mathrm{LG}=\mathrm{TMR}$ containing long corn silage, $\mathrm{MSH}=\mathrm{TMR}$ composed of 1 part LG, 2 parts SH, MLG = TMR composed of 2 parts LG, 1 part SH.

${ }^{2} \mathrm{TC}=$ total chewing activity ( $\mathrm{min}$ eating + min ruminating).

${ }^{3} \mathrm{NDFI}=\mathrm{NDF}$ intake. 
Table 7. Effects of feeding corn silage of reduced particle size to lactating dairy cows on consumption of $\mathrm{DM}$ and NDF at 8,16 , and $24 \mathrm{~h}$ postfeeding.

\begin{tabular}{|c|c|c|c|c|c|c|c|c|}
\hline \multirow[b]{2}{*}{ Hour } & \multicolumn{4}{|c|}{ Treatment $^{1}$} & \multirow[b]{2}{*}{ SEM } & \multicolumn{3}{|c|}{ Contrast } \\
\hline & $\mathrm{SH}$ & $\mathrm{MSH}$ & MLG & $\mathrm{LG}$ & & Linear & Quadratic & Cubic \\
\hline \multicolumn{9}{|c|}{$\mathrm{DMI},{ }^{2} \mathrm{~kg}$} \\
\hline 8 & 17.8 & 15.2 & 16.0 & 17.2 & 1.2 & 0.79 & 0.06 & 0.45 \\
\hline 16 & 25.8 & 25.0 & 23.7 & 24.3 & 1.4 & 0.02 & 0.23 & 0.28 \\
\hline 24 & 28.6 & 27.3 & 25.3 & 26.3 & 1.0 & 0.01 & 0.03 & 0.11 \\
\hline \multicolumn{9}{|c|}{$\mathrm{NDFI},{ }^{3} \mathrm{~kg}$} \\
\hline 8 & 5.4 & 5.3 & 5.2 & 5.3 & 0.4 & 0.57 & 0.64 & 0.54 \\
\hline 16 & 8.4 & 8.4 & 8.0 & 7.7 & 0.4 & $<0.01$ & 0.02 & 0.05 \\
\hline 24 & 9.5 & 9.2 & 8.8 & 8.8 & 0.3 & $<0.01$ & 0.07 & 0.09 \\
\hline
\end{tabular}

${ }^{1} \mathrm{SH}=$ TMR containing short corn silage, $\mathrm{LG}=\mathrm{TMR}$ containing long corn silage, $\mathrm{MSH}=\mathrm{TMR}$ composed of 1 part LG, 2 parts SH, MLG = TMR composed of 2 parts LG, 1 part SH.

${ }^{2} \mathrm{As}$ determined on days eating activity was measured.

${ }^{3} \mathrm{NDFI}=\mathrm{NDF}$ intake; as determined on days eating activity was measured.

paring original TMR particle size to orts remaining after $24 \mathrm{~h}$, the proportion of DM retained on the 1.18$\mathrm{mm}$ sieve and pan decreased significantly (16.0 and $3.1 \%$ ) for treatment LR, but decreased only moderately $(0.4$ and $0.6 \%)$ for diet $\mathrm{SH}$.

Using cumulative intake and refusal particle size data collected at 8, 16, and $24 \mathrm{~h}$ postfeeding, consumption of material of each particle size fraction was calculated (Table 9). As particle size of the ration decreased, a linear decrease in consumption of particles $>19.0$ mm was observed at 8,16 , and $24 \mathrm{~h}$ postfeeding. In contrast, reducing forage particle size linearly increased consumption of particles 8.0 to $19.0 \mathrm{~mm}$ at each time point. A quadratic effect on intake of material 1.18 to $8.0 \mathrm{~mm}$ in length was observed at 8 and 16 $\mathrm{h}$ postfeeding, but after $24 \mathrm{~h}$ intake increased linearly with reduced particle size.

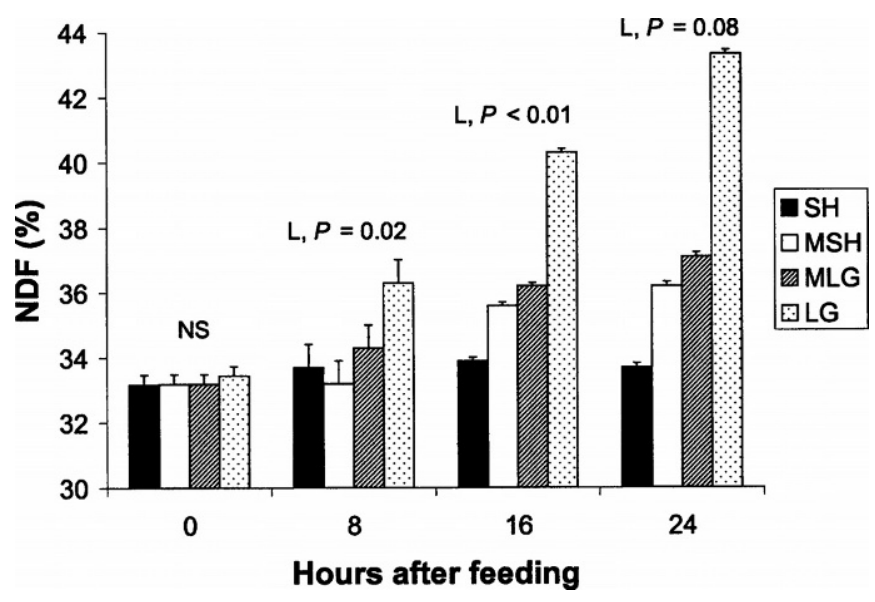

Figure 1. The effect of reducing corn silage particle size on NDF content of feed $(0 \mathrm{~h})$ or orts 8,16 , and $24 \mathrm{~h}$ after feeding.

\section{Rumen $\mathrm{pH}$ and Concentration of VFA and Ammonia}

Effects of corn silage particle size on rumen $\mathrm{pH}$, total VFA, ammonia concentrations, and molar proportion of individual VFA are presented in Table 10. Treatment $\times$ time interaction effects were not significant for $\mathrm{pH}, \mathrm{VFA}$, and ammonia measurements. Rumen $\mathrm{pH}$ only tended to have a linear effect with reduced particle size even though total concentration of VFA increased linearly from 89.1 to $93.6 \mathrm{mM} / \mathrm{L}$ as particle size was reduced. Reducing particle size resulted in a quadratic effect on concentration of propionate (data not shown) with highest concentration observed in animals consuming diets of shortest particle size (23.0, 20.6, 20.5, $21.7 \mathrm{kd} / \mathrm{d}$ for SH, MSH, MLG, and LG, respectively). Molar proportion of acetate as well as acetate-to-propionate ratio exhibited a quadratic effect, with highest values observed on MSH and MLG treatments. Rumen ammonia concentration did not differ between treatments and averaged $8.7 \mathrm{mg} / \mathrm{dl}$.

\section{Milk Production, Composition, and Body Weight Change}

Milk production and composition data are presented in Table 11. Milk yield was similar across diets and averaged $41.6 \mathrm{~kg}$. However, a quadratic effect was observed for $3.5 \% \mathrm{FCM}$ with highest production observed on the MSH and MLG treatments. Yield and percent of milk fat responded quadratically to reduced particle size; highest values were observed on MSH and MLG treatments. No effect was observed for yield or percent milk protein, which averaged $1.17 \mathrm{~kg} / \mathrm{d}$ and $2.8 \%$ across all treatments. 
Table 8. Effects feeding corn silage of reduced particle size to lactating dairy cows on the particle size of feed remaining in the bunk 8, 16, and $24 \mathrm{~h}$ after feeding, as described by the Penn State Particle Separator.

\begin{tabular}{|c|c|c|c|c|c|c|c|c|}
\hline \multirow[b]{2}{*}{ Hour } & \multicolumn{4}{|c|}{ Treatment $^{1}$} & \multirow[b]{2}{*}{ SEM } & \multicolumn{3}{|c|}{ Contrast } \\
\hline & $\mathrm{SH}$ & $\mathrm{MSH}$ & MLG & LG & & Linear & Quadratic & Cubic \\
\hline & & $\% \mathrm{DM}$ & ained & - & & & & \\
\hline \multicolumn{9}{|c|}{$19.0 \mathrm{~mm}$} \\
\hline 0 & 2.9 & 6.7 & 11.1 & 15.5 & 0.8 & $<0.01$ & 0.74 & 0.84 \\
\hline 8 & 4.7 & 6.7 & 11.4 & 21.0 & 1.4 & $<0.01$ & 0.03 & 0.69 \\
\hline 16 & 7.8 & 13.5 & 15.5 & 30.0 & 3.0 & $<0.01$ & 0.04 & 0.12 \\
\hline 24 & 9.5 & 25.8 & 28.7 & 60.2 & 3.9 & $<0.01$ & 0.13 & 0.06 \\
\hline \multicolumn{9}{|c|}{$8.0 \mathrm{~mm}$} \\
\hline 0 & 57.5 & 55.7 & 53.2 & 50.3 & 0.4 & $<0.01$ & 0.17 & 0.79 \\
\hline 8 & 51.6 & 46.3 & 45.7 & 44.9 & 0.8 & $<0.01$ & 0.04 & 0.21 \\
\hline 16 & 48.7 & 39.4 & 40.6 & 34.6 & 2.2 & $<0.01$ & 0.34 & 0.04 \\
\hline 24 & 50.8 & 40.1 & 41.9 & 22.3 & 2.8 & $<0.01$ & 0.06 & 0.01 \\
\hline \multicolumn{9}{|c|}{$1.18 \mathrm{~mm}$} \\
\hline 0 & 35.3 & 33.8 & 31.9 & 30.3 & 0.7 & $<0.01$ & 0.95 & 0.82 \\
\hline 8 & 38.4 & 40.0 & 37.1 & 29.0 & 1.6 & $<0.01$ & 0.03 & 0.95 \\
\hline 16 & 38.4 & 40.2 & 37.3 & 22.6 & 2.6 & $<0.01$ & 0.02 & 0.55 \\
\hline 24 & 34.9 & 30.5 & 28.7 & 14.3 & 2.3 & $<0.01$ & 0.11 & 0.22 \\
\hline \multicolumn{9}{|c|}{$<1.18 \mathrm{~mm}$} \\
\hline 0 & 4.2 & 4.0 & 3.9 & 3.9 & 0.2 & 0.33 & 0.75 & 0.95 \\
\hline 8 & 4.9 & 7.2 & 6.7 & 4.4 & 0.8 & 0.56 & 0.01 & 0.71 \\
\hline 16 & 5.1 & 7.0 & 7.4 & 2.7 & 1.1 & 0.14 & $<0.01$ & 0.35 \\
\hline 24 & 3.6 & 4.6 & 3.3 & 0.8 & 1.1 & 0.05 & 0.09 & 0.81 \\
\hline
\end{tabular}

${ }^{1} \mathrm{SH}=\mathrm{TMR}$ containing short corn silage, $\mathrm{LG}=\mathrm{TMR}$ containing long corn silage, $\mathrm{MSH}=\mathrm{TMR}$ composed of 1 part LG, 2 parts SH, MLG = TMR composed of 2 parts LG, 1 part SH.

\section{DISCUSSION}

The particle size of corn silage may be influenced by type and settings of harvesting equipment or plant maturity and may affect packing density and fermentation of silage (Johnson et al., 2002, 2003). In a survey of over 5000 samples, Heinrichs et al. (1999) reported that on average corn silage samples fed on commercial dairy farms contain $8.1 \pm 6.4 \%$ of the DM greater than $19.0 \mathrm{~mm}$, but variation across herds is large. In the same survey, a minimum of $1 \%$ and a maximum of $81 \%$ of DM was $>19.0 \mathrm{~mm}$. In the current study parti-

Table 9. Effects of feeding corn silage of reduced particle size to lactating dairy cows on consumption of different size particles as described by the Penn State Particle Separator.

\begin{tabular}{|c|c|c|c|c|c|c|c|c|}
\hline \multirow[b]{2}{*}{ Hour } & \multicolumn{4}{|c|}{ Treatment $^{1}$} & \multirow[b]{2}{*}{ SEM } & \multicolumn{3}{|c|}{ Contrast } \\
\hline & $\mathrm{SH}$ & $\mathrm{MSH}$ & MLG & LG & & Linear & Quadratic & Cubic \\
\hline & 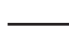 & ount co & hed $(\mathrm{kg}$ & 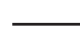 & & & & \\
\hline \multicolumn{9}{|c|}{$19.0 \mathrm{~mm}$} \\
\hline 8 & 0.3 & 1.1 & 1.7 & 2.0 & 0.3 & $<0.01$ & 0.37 & 0.80 \\
\hline 16 & 0.6 & 1.4 & 2.3 & 2.9 & 0.4 & $<0.01$ & 0.79 & 0.72 \\
\hline 24 & 0.8 & 1.4 & 2.3 & 3.1 & 0.3 & $<0.01$ & 0.81 & 0.78 \\
\hline \multicolumn{9}{|c|}{$8.0 \mathrm{~mm}$} \\
\hline 8 & 11.1 & 10.2 & 9.6 & 9.4 & 0.6 & 0.05 & 0.43 & 0.99 \\
\hline 16 & 16.1 & 15.3 & 13.4 & 13.3 & 0.6 & $<0.01$ & 0.26 & 0.09 \\
\hline 24 & 17.3 & 16.1 & 14.6 & 14.1 & 0.5 & $<0.01$ & 0.26 & 0.46 \\
\hline \multicolumn{9}{|c|}{$1.18 \mathrm{~mm}$} \\
\hline 8 & 5.7 & 4.3 & 4.3 & 5.2 & 0.5 & 0.52 & 0.06 & 0.72 \\
\hline 16 & 9.0 & 8.0 & 7.2 & 7.9 & 0.5 & 0.04 & 0.04 & 0.34 \\
\hline 24 & 10.2 & 9.5 & 8.4 & 8.4 & 0.4 & $<0.01$ & 0.12 & 0.13 \\
\hline \multicolumn{9}{|c|}{$<1.18 \mathrm{~mm}$} \\
\hline 8 & 0.5 & 0.3 & 0.4 & 0.6 & 0.1 & 0.84 & 0.09 & 0.90 \\
\hline 16 & 1.0 & 0.7 & 0.6 & 0.9 & 0.1 & 0.53 & 0.01 & 0.29 \\
\hline 24 & 1.2 & 1.0 & 0.9 & 0.9 & 0.1 & $<0.01$ & 0.02 & 0.81 \\
\hline
\end{tabular}

${ }^{1} \mathrm{SH}=\mathrm{TMR}$ containing short corn silage, $\mathrm{LG}=\mathrm{TMR}$ containing long corn silage, $\mathrm{MSH}=\mathrm{TMR}$ composed of 1 part LG, 2 parts SH, MLG = TMR composed of 2 parts LG, 1 part SH. 
Table 10. Effects of reducing corn silage particle size on ruminal $\mathrm{pH}$, ammonia, total concentration of VFA, and molar proportion of VFA of lactating dairy cattle.

\begin{tabular}{|c|c|c|c|c|c|c|c|c|}
\hline & \multicolumn{4}{|c|}{ Treatment $^{1}$} & \multirow[b]{2}{*}{ SEM } & \multicolumn{3}{|c|}{ Contrast } \\
\hline & $\mathrm{SH}$ & MSH & MLG & LG & & Linear & Quadratic & Cubic \\
\hline $\mathrm{pH}$ & 6.3 & 6.4 & 6.3 & 6.4 & 0.10 & 0.14 & 0.63 & 0.09 \\
\hline Total VFA $(\mathrm{m} M)$ & 93.6 & 89.1 & 87.8 & 89.1 & 3.1 & 0.07 & 0.10 & 0.95 \\
\hline \multicolumn{9}{|l|}{ VFA $(\mathrm{mol} / 100 \mathrm{~mol})$} \\
\hline Acetate & 59.6 & 60.8 & 60.7 & 59.9 & 0.9 & 0.44 & $<0.01$ & 0.57 \\
\hline Propionate & 24.3 & 23.0 & 23.4 & 24.1 & 1.0 & 0.82 & $<0.01$ & 0.25 \\
\hline Isobutyrate & 0.9 & 1.0 & 1.0 & 1.0 & 0.03 & 0.04 & 0.26 & 0.99 \\
\hline Butyrate & 11.5 & 11.6 & 11.4 & 11.3 & 0.2 & 0.18 & 0.79 & 0.50 \\
\hline Isovalerate & 1.7 & 1.8 & 1.8 & 1.8 & 0.2 & 0.20 & 0.04 & 0.16 \\
\hline Valerate & 1.9 & 1.9 & 1.8 & 1.9 & 0.03 & $<0.01$ & $<0.01$ & 0.46 \\
\hline Acetate:propionate & 2.5 & 2.7 & 2.6 & 2.5 & 0.1 & 0.44 & $<0.01$ & 0.47 \\
\hline $\mathrm{NH}_{3} \mathrm{~N}(\mathrm{mg} / \mathrm{dl})$ & 9.1 & 8.4 & 8.3 & 9.1 & 0.8 & 0.94 & 0.15 & 0.83 \\
\hline
\end{tabular}

${ }^{1} \mathrm{SH}=\mathrm{TMR}$ containing short corn silage, $\mathrm{LG}=\mathrm{TMR}$ containing long corn silage, $\mathrm{MSH}=\mathrm{TMR}$ composed of 1 part LG, 2 parts SH, MLG = TMR composed of 2 parts LG, 1 part SH.

cles $>19.0 \mathrm{~mm}$ comprised $6.8 \%$ in the shortest corn silage and $25.9 \%$ in the longest corn silage, thus particle size of silage was within the range of silage fed on commercial dairy farms.

Results of this study indicate that DMI is increased by reducing corn silage particle size. These results are similar to some previous studies (Stockdale and Beavis, 1994; Weigand et al., 1992); however, this effect has not been observed in others (Schwab and Shaver, 2002; Kononoff and Heinrichs, 2003b). Reducing particle size also linearly increased total NDFI and linearly decreased NDF content of orts. Although increased consumption of NDF on shorter diets was in part due to higher DMI, reducing particle size also resulted in less sorting and greater consumption of coarse, high fiber particles. Methu et al. (2001) reported similar effects when feeding corn silage of different particle size. Bal et al. (2000) also observed a decrease in sorting tendency when feeding cows kernel processed corn silage. In the present study, NDF content of feed remaining in the bunk after 8,16 , and 24 $\mathrm{h}$ was linearly reduced as corn silage particle size in the ration decreased (Figure 1). These results clearly demonstrate that sorting activity occurred during the first $8 \mathrm{~h}$ after feeding and continued over the entire 24-h period. Particle size differences between original TMR and feed remaining in the bunk 8,16 , and $24 \mathrm{~h}$ postfeeding increased, thus supporting the suggestion that reducing corn silage particle size will reduce sorting behavior. Clearly some sorting behavior was observed in diets of shortest particle size; DM $>19.0 \mathrm{~mm}$ increased from $2.8 \%$ in the original TMR to $9.5 \%$ in orts after $24 \mathrm{~h}$. Highest sorting was observed on the TMR of longest particle size; DM $>19.0 \mathrm{~mm}$ increased from $15.5 \%$ in the original TMR to $60.2 \%$ in orts after $24 \mathrm{~h}$. Diets of longer particle size resulted in greater consumption of small particles that measure 1.18 to $8.0 \mathrm{~mm}$ and $<1.18 \mathrm{~mm}$ than diets with shorter particle size. Practically, it may be important to consider that even though fine chopping or processing corn silage increases power requirements and harvest costs, reduced sorting behavior should be observed when these forages are fed to lactating dairy cattle.

Although a number of studies have evaluated the effect of corn silage particle size on eating and ruminating behavior, the current study is unique because

Table 11. Effects of reducing corn silage particle size on milk production and composition of lactating dairy cattle.

\begin{tabular}{|c|c|c|c|c|c|c|c|c|}
\hline & \multicolumn{4}{|c|}{ Treatment $^{1}$} & \multirow[b]{2}{*}{ SEM } & \multicolumn{3}{|c|}{ Contrast } \\
\hline & $\mathrm{SH}$ & MSH & MLG & LG & & Linear & Quadratic & Cubic \\
\hline Milk yield, kg/d & 41.3 & 42.3 & 41.5 & 41.1 & 1.88 & 0.78 & 0.41 & 0.56 \\
\hline $3.5 \%$ FCM, kg/d & 43.1 & 44.8 & 44.6 & 42.4 & 0.8 & 0.67 & 0.06 & 0.99 \\
\hline Fat $\%$ & 3.7 & 3.9 & 4.0 & 3.7 & 0.3 & 0.89 & 0.03 & 0.43 \\
\hline Fat, kg/d & 1.6 & 1.6 & 1.6 & 1.5 & 0.1 & 0.68 & 0.03 & 0.77 \\
\hline Protein \% & 2.8 & 2.8 & 2.8 & 2.8 & 0.04 & 0.56 & 0.59 & 0.91 \\
\hline Protein, kg/d & 1.2 & 1.2 & 1.2 & 1.2 & 0.04 & 0.94 & 0.41 & 0.73 \\
\hline
\end{tabular}

${ }^{1} \mathrm{SH}=\mathrm{TMR}$ containing short corn silage, $\mathrm{LG}=\mathrm{TMR}$ containing long corn silage, $\mathrm{MSH}=\mathrm{TMR}$ composed of 1 part LG, 2 parts SH, MLG = TMR composed of 2 parts LG, 1 part SH. 
it evaluates the intake, particle size, and fiber content of feed originally offered to the animals as well as that remaining over $24 \mathrm{~h}$. As expected, animals consuming diets of shortest particle size consumed the fewest particles $>19.0 \mathrm{~mm}(0.8 \mathrm{~kg} / \mathrm{d})$. Even though animals consuming diets containing long corn silage refused the largest amount of longest particles, they consumed the greatest amount of material $>19.0 \mathrm{~mm}(3.1 \mathrm{~kg} / \mathrm{d})$. We originally hypothesized that reducing particle size would reduce TC (minutes per day), but a quadratic effect was observed with diets of intermediate particle size having lowest values. It is plausible that the observed response is a function of two competing effects, total intake and intake of long particles $(>19.0 \mathrm{~mm})$. Thus, although animals consuming the SH treatment consumed the least amount of particles $>19.0 \mathrm{~mm}$, this diet was consumed in greatest amounts. In comparison, animals consuming the LG treatment consumed the largest amount of particles $>19.0 \mathrm{~mm}$ but had the lowest DMI. In support of this suggestion, when normalized for intake, reducing corn silage particle size was observed to result in a linear reduction in TC per unit of DM and NDF consumed. This result was similar to that observed in a study that evaluated effects of reducing alfalfa haylage particle size (Kononoff and Heinrichs, 2003a). In that study, it was suggested that increasing the proportion of particles $>19.0 \mathrm{~mm}$ may be a primary factor affecting chewing activity of dairy cattle. In the current study, both the proportion and total intake of feed particles $>19.0 \mathrm{~mm}$ decreased with reduced particle size, while the proportion and intake of particles 8.0 to $19.0 \mathrm{~mm}$ and 8.0 to $1.18 \mathrm{~mm}$ increased with reduced particle size. Thus the results of this study would further suggest that although particles $>19.0 \mathrm{~mm}$ are most likely to be refused by dairy cattle, this particle fraction of the PSPS best reflects TC per unit of DM and NDF intake.

Differences between silage particle size and, presumably, eating behavior also resulted in differences in rumen fermentation. Similar to the effects on intake, total concentration of VFA increased with reduced particle size. These observations are consistent with other studies in which the reduction in particle size of both alfalfa haylage (Kononoff and Heinrichs, 2003a) and barley silage (Soita et al., 2002) resulted in increased DMI and rumen VFA concentration. In addition to these observations, highest molar proportion of acetate and lowest molar proportion of propionate was observed on diets of intermediate particle size and may have been a result of two competing effects namely, starch digestibility and fiber intake. We speculate that a lower proportion of acetate and higher proportion of propionate on diets of shortest particle size may have been due to increased starch digestibility, which may be associated with reducing corn silage particle size (Johnson et al., 2003). In comparison, due to sorting behavior diets of longest particle size resulted in the lowest NDFI, which is known to decrease rumen molar proportion of acetate and increase molar proportion of propionate (Van Soest, 1994).

Although it is commonly believed that increased silage particle size will result in increased chewing activity and salivary buffer production, rumen $\mathrm{pH}$ was not different across treatments. This observation is consistent with Yang et al. (2002). Although differences in rumen $\mathrm{pH}$ could be expected given the differences in VFA concentration, the observed results may illustrate a lack of effect of increased chewing activity on buffering the rumen environment. These results support the suggestion that increasing chewing activity by feeding forage of longer particle size does not substantially increase daily saliva output to affect rumen $\mathrm{pH}$. The lack of effect may be due to the fact that saliva is also secreted while cows are resting and that rumen fermentability of starch may be more important in understanding the extent of subclinical ruminal acidosis (Yang et al., 2000).

Due to the short experimental periods and small number of animals used, milk production results of the current experiment should be interpreted with caution. Total milk yield, protein percentage, and yield were not affected by particle size reduction. A quadratic response was observed for 3.5\% FCM, milk fat percentage, and yield. Highest milk fat levels were paired with highest ratio of acetate-to-propionate on intermediate treatments, and lowest fat levels were similarly paired with lowest acetate to propionate ratio on shortest and longest ration particle size treatments. These observations are consistent with observations of Grant et al. (1990) and Le Liboux and Peyraud (1998) in which diets of reduced particle size and lower consumption of fiber decreased the ratio of acetate to propionate and paired with lower milk fat. Although it is generally accepted that trans fatty acid formation in the rumen directly affects de novo milk fat synthesis (Baumgard et al., 2000), understanding of the impact of feeding diets with finer particle size on ruminal formation of trans fatty acid remains incomplete and should be further investigated.

Current NRC (2001) recommendations state that diets fed to lactating dairy cows must contain a minimum of $25 \%$ NDF but do not clearly specify guidelines for physical form. Because it is widely understood that forage particle size can influence rumen $\mathrm{pH}$ and fermentation, presumably by influencing chewing activity, a number of studies have been designed to investigate the effect of corn silage particle size on chewing 
activities and rumen $\mathrm{pH}$ of lactating dairy cattle. In the current study reducing corn silage particle size did not affect total time spent eating, which was similar to other reports (Bal et al., 2000; Schwab et al., 2002). However, a quadratic effect was observed in which longest time spent chewing was observed on the shortest and longest rations. When time spent chewing was normalized per unit of NDFI, total time spent chewing decreased as particle size was reduced. The results of this study are similar to those reported by Krause et al. (2002), in which physical effectiveness of diet NDF decreased with decreasing forage particle size. Given this observation, one may conclude that reducing corn silage particle size reduced effectiveness and should result in reduced chewing activity. However, in the current study, total time spent chewing was elevated, presumably due to the higher intake of fiber, which is also known to stimulate chewing activity. Practically, it is important to understand that corn silage of shorter particle size actually may be more effective in stimulating chewing activity based on the amount of NDF consumed and that reducing particle size may also minimize sorting behavior.

\section{CONCLUSIONS}

Reducing corn silage particle size increased DMI of lactating dairy cattle. Although chewing activity was closely related to corn silage particle size as we originally hypothesized, effects on rumen $\mathrm{pH}$ were not observed, thus indicating other factors are also critical in regulation of rumen $\mathrm{pH}$. Feeding a corn silage-based diet with $2.9 \%$ compared with $15.5 \%$ of the particles $>19.0 \mathrm{~mm}$ increased total rumen VFA concentration $4.5 \mathrm{mM} / \mathrm{L}$ and was likely a function of animals consuming $2.3 \mathrm{~kg}$ more feed. Because mean rumen $\mathrm{pH}$ was not affected, it is concluded that physical effectiveness of corn silage was not affected by reducing particle size. In addition, the results of the study suggest that increasing particle size of corn silage may increase sorting behavior of the animal. Lastly, results demonstrate that measurement of particle size using the PSPS is useful in understanding factors that affect feeding behavior and that the proportion of particles $>19.0 \mathrm{~mm}$ may be a good indicator of TC and bunk sorting behavior.

\section{ACKNOWLEDGMENTS}

This research was supported in part by USDA grant no. 2001-34281-11219. The assistance of M. Long with assays and sample collection is much appreciated, as is the thorough editing by C. Jones. Our appreciation to students T. Ross, B. Zary, A. Zeladonis, E. Samras,
A. Gehman, D. Schup and T. Haltman for feed preparation, sample collection, and analysis.

\section{REFERENCES}

ASAE. 2001. Method of determining and expressing particle size of chopped forage materials by sieving. S424 in Standards. Am. Soc. Agric. Eng., St. Joseph, MI.

Association of Official Analytical Chemists. 1990. Official Methods of Analysis. 15th ed. AOAC, Arlington, VA.

Bal, M. A., R. D. Shaver, A. G. Jirovec, K. J. Shinners, and J. G. Coors. 2000. Crop processing and chop length of corn silage: Effects on intake, digestion, and milk production by dairy cows. J. Dairy Sci. 83:1264-1273.

Baumgard, L. H., B. A. Coral, D. A. Dwyer, A. Saebo, and D. E. Bauman. 2000. Identification of the conjugated linoleic acid isomer that inhibits milk fat synthesis. Am. J. Physiol. 278:R179-R184.

Broderick, G. A., and J. H. Kang. 1980. Automated simultaneous determination of ammonia and total amino acids in ruminal fluid and in vitro media. J. Dairy Sci. 63:64-75.

Grant, R. J., V. F. Colenbrander, and D. R. Mertens. 1990. Milk fat depression in dairy cows: role of silage particle size. J. Dairy Sci. 73:1834-1842

Heinrichs, A. J., D. R. Buckmaster, and B. P. Lammers. 1999. Processing, mixing, and particle size reduction of forages for dairy cattle. J. Anim. Sci. 77:180-186.

Johnson, L., J. H. Harrison, D. Davidson, J. Robutti, M. Swift, B. Mahanna, and K. Shinners. 2002. Corn silage management I. Effects of hybrid, maturity, mechanical processing, on chemical and physical characteristics. J. Dairy Sci. 85:833-853.

Johnson, L. M., J. H. Harrison, D. Davidson, W. C. Mahanna, and K. Shinners. 2003. Corn silage management: Effect of hybrid, chop length, and mechanical processing on digestion and energy content. J. Dairy. Sci. 86:208-231.

Kalscheur, K. F., B. B. Neter, L. S. Piperova, and R. A. Erdman. 1997. Effect of dietary forage concentration and buffer addition on duodenal flow of trans- $\mathrm{C}_{18: 1}$ fatty acids and milk fat production in dairy cows. J. Dairy Sci. 80:2104-2114.

Kononoff, P. J., H. A. Lehman, and A. J. Heinrichs. 2002. A comparison of methods used to measure eating and ruminating activity in confined dairy cattle. J. Dairy Sci. 85:1801-1803.

Kononoff, P. J., A. J. Heinrichs, and D. R. Buckmaster. 2003. Modification of the Penn State Particle Separator and the effects of moisture content on its measurements. J. Dairy Sci. 86:18581863

Kononoff, P. J., and A. J. Heinrichs. 2003a. The effect of reducing alfalfa haylage particle size on cows in early lactation. J. Dairy Sci. 86:1445-1457.

Kononoff, P. J., and A. J. Heinrichs. 2003b. The effect of corn silage particle size and cottonseed hulls on cows in early lactation. J. Dairy Sci. 86:2438-2451.

Krause, K. M., D. K. Combs, and K. A. Beauchemin. 2002. Effects of forage particle size and grain fermentability in midlactation cows II. Ruminal $\mathrm{pH}$ and chewing activity. J. Dairy Sci. 85:1947-1957.

Le Liboux, S., and J. L. Peyraud. 1998. Effect of forage particle size and intake level on fermentation patterns and sites and extent of digestion in dairy cows fed mixed diets. Anim. Feed Sci. Technol. 73:131-150.

McDonald, P. 1981. The Biochemistry of Silage. John Wiley \& Sons, New York, NY

Mertens, D. R. 1997. Creating a system for meeting the fiber requirements of dairy cattle. J. Dairy Sci. 80:1463-1482.

Methu, J. N., E. Owen, A. L. Abate, and J. C. Tanner. 2001. Botanical and nutritional composition of maize stover, intakes, and feed selection by dairy cattle. Livest. Prod. Sci. 71:87-97.

National Research Council. 2001. Nutrient Requirements of Dairy Cattle. 7th rev. ed. Natl. Acad. Sci., Washington, DC. 
Rodrigue, C. B., and N. N. Allen. 1960. The effect of fine grinding of hay on ration digestibility, rate of passage, and milk fat content of milk. Can. J. Anim. Sci. 40:23-29.

Rutter, S. M., R. A. Champion, and P. D. Penning. 1997. An automatic system to record foraging behavior in free-ranging ruminants. Appl. Anim. Behav. Sci. 54:185-195.

SAS User's Guide: Statistics, Version 8.0 Edition. 1999. SAS Inst., Inc., Cary, NC.

Schwab, E. C., R. D. Shaver, K. J. Shinners, J. G. Lauer, and J. G. Coors. 2002. Processing and chop length effects in brown-midrib corn silage on intake, digestion, and milk production by dairy cows. J. Dairy Sci. 85:613-623.

Smith, D. 1981. Removing and analyzing carbohydrates from plant tissue. Rep. No. R2107. Wisconsin Agric. Exp. Stn., Madison.

Soita, H. W., D. A. Christensen, J. J. McKinnon, and A. F. Mustafa. 2002. Effects of barley silage of different theoretical cut length on digestion kinetics in ruminants. Can. J. Anim. Sci. 82:207-213.

Stockdale, C. R., and G. W. Beavis. 1994. Nutritional evaluation of whole plant maize ensiled at three chop lengths and fed to lactating dairy cattle. Aust. J. Exp. Agric. 34:709-716.
Van Soest, P. J. 1994. Nutritional Ecology of the Ruminant. 2nd ed. Comstock Publishing Associated, Ithaca, NY

Van Soest, P. J., J. B. Robertson, and B. A. Lewis. 1991. Methods for dietary fiber, neutral detergent fiber and non-starch polysaccharides in relation to animal nutrition. J. Dairy Sci. 74:3583-3597.

Weigand, E., U. Meyer, and N. Guth. 1993. Intake, chewing activity and carbohydrate digestibility by lactating dairy cows fed maize silage with different physical structure. J. Anim. Physiol. Anim. Nutr. 69:120-132.

Woodford, S. T., and M. R. Murphy. 1988. Effect of physical form of forage on chewing activity, dry matter intake, and rumen function of dairy cows in early lactation. J. Dairy Sci. 71:674686.

Yang, C. M. J., and G. A. Varga. 1989. Effect of three concentrate feeding frequencies on rumen protozoa, rumen digesta kinetics, and milk yield in dairy cows. J. Dairy Sci. 72:950-957.

Yang, W. Z., K. A. Beauchemin, and L. A. Rode. 2001. Effects of grain processing, forage to concentrate ratio, and forage particle size on rumen $\mathrm{pH}$ and digestion by dairy cattle. J. Dairy Sci. 84:2203-2216. 